\author{
ZYGMUNT BROGOWSKI $^{1}$, WOJCIECH KWASOWSKI ${ }^{1 *}$, RENATA MADYNIAK ${ }^{2}$ \\ ${ }^{1}$ Warsaw University of Life Sciences - SGGW, Faculty of Agriculture and Biology, Department of Soil Environment Sciences \\ 159 Nowoursynowska Str., 02-776 Warsaw, Poland \\ ${ }^{2}$ Warsaw University of Life Sciences - SGGW, Analytical Centre, 8 Ciszewskiego Str., 02-786 Warszawa
}

\title{
Calculating particle density, bulk density, and total porosity of soil based on its texture
}

\begin{abstract}
This paper provides the verification of coefficients for the calculation of particle density, bulk density, and total porosity based on the texture of soils proposed by Brogowski (1990). The verified and supplemented coefficients for the calculation of particle density, bulk density, and total porosity permit obtaining credible results within the range of analytical errors. The proposed calculations of density and total porosity of soils can be used for the general description of soils. They cannot, however, replace exact scientific research on the physical state of soils.
\end{abstract}

Key words: particle density, bulk density, total porosity, soil texture

\section{INTRODUCTION}

The growth of plants is determined among others by the physical state of the soil environment. The density and porosity of soils determine the possibility of water binding, air movement, penetration of plant roots, etc. (e.g. Arvidsson 1998; Carter 1990; Brogowski 1990; Hakansson and Lipiec 2000; Keller Hakansson 2010; Lipiec et al. 1991; Turski et al. 1974; Raczuk 1987; Wojtasik 1988, 1989; Uziak et al. 2005).

The majority of researchers treat soil as a whole in physical terms. Scarce studies concern particular groups of soil grains, i.e. granulometric fractions (Raczuk 1987; Turski et al. 1974; Uziak et al. 2005; Brogowski 1990; Keller and Hakansson 2010). This results from a very strenuous procedure of extracting particular granulometric fractions from soils.

This paper provides the verification of coefficients for the calculation of particle density, bulk density, and total porosity based on the texture of soils proposed by Brogowski (1990). The results obtained by research teams of the Departments of Soil Sciences from the Maria Curie-Skłodowska University in Lublin, Warsaw University of Life Sciences - SGGW, and University of Agriculture in Kraków (Uziak et al. 2005) were involved in the verification. The research concerned the chemical, physical-chemical, and physical properties of granulometric fractions separated from loess soil, as well as soils from mountainous areas and central Poland. The research was financed by the Institute of Agrophysics of the Polish Academy of Sciences in Lublin.

\section{MATERIALS AND METHODS}

Due to the abundance of numerical material, the paper only provides some of the results concerning particle density, bulk density, and total porosity. It presents results of the analyses of the physical properties of granulometric fractions of soils with a varied genesis of soil materials, namely: heavy boulder clay (Gąbin), loamy boulder sand (Zamość, Ostrołęka district), formation of the old Vistula River terrace (Kazuń), and modern alluvial formation (WilanówWarszawa). All of the soils are Endoeutric Cambisols.

The soils were separated into granulometric fractions by means of the Atterberg's method by all of the three research teams. The soil was boiled for a period of 30 minutes with no addition of a peptiser. The procedure was selected due to the behaviour of organic compounds in the natural state. Peptization causes the dissolution of organic compounds present in the clay fraction. Boiling and mixing with a rotary stirrer was performed until the complete extraction of the clay fraction $<0.002 \mathrm{~mm}$. The extraction was compared (verified) by means of performing analyses of the soil using the Cassagrande's method modified by Prószyński. Fractions $>0.002 \mathrm{~mm}$ were extracted with no further boiling, only mixing with a stirrer for a period of 10 minutes, until complete extraction of a given fraction. The fractions were dried in a dryer at a temperature of $70-75^{\circ} \mathrm{C}$.

Particle density was determined by the picnometric method in two repetitions. Bulk density was determined by means of the bulk method using glass scaled cylinders with a volume of $100 \mathrm{~cm}^{3}$. After filling 
a cylinder was weighed, and bulk density was calculated. The determination was performed in an average of three or four repetitions, particularly in the case of fine fractions $<0.02 \mathrm{~mm}$. The fractions are composed of clay minerals and humus with varied morphological structure. It is very difficult to press it to the natural state encountered in soils.

The determined densities provided the basis for the calculation of total porosity of a particular fraction.

Based on the obtained results, coefficients were determined for the calculation of particle density, bulk density, and total porosity (Brogowski 1990). The obtained results for Polish mountainous soils and Lublin loess soils suggested that the verification of the coefficients is only required for soils developed from loesses (Table 5).

Example of calculation of particle density of soil with determined grain structure:

The soil's grain structure in horizon Ap of soil developed from heavy loam (Gąbin, Table 1).

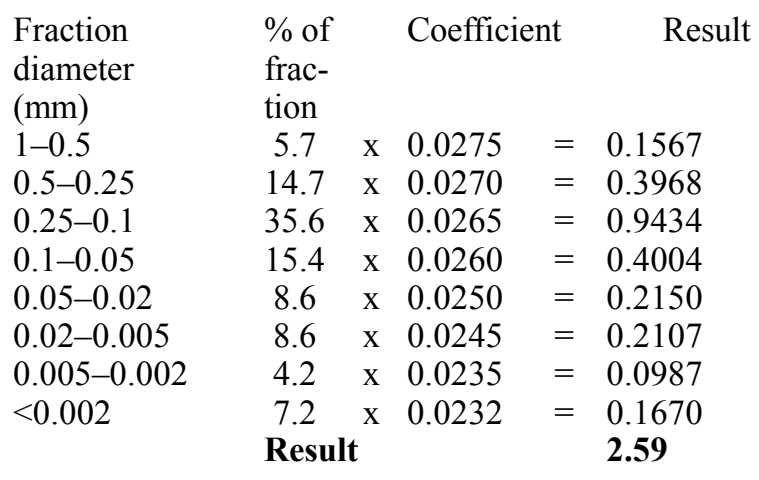

The result obtained by the picnometric method amounts to 2.58 (Table 2).

Such accuracy can be considered sufficient for the general description of the basic soil parameters.

\section{RESULTS}

The texture of the selected soils is considerably varied. Sand grains $(1-0.1 \mathrm{~mm})$ constitute the dominant fraction in the soils, except for the alluvial soils from Warszawa-Wilanów. The second fraction in quantitative terms are grains with a diameter of $0.1-0.02 \mathrm{~mm}$, and the third one - clay fraction $<0.002 \mathrm{~mm}$. The lowest contribution in the mass of the studied soils is reached by grains with a diameter of $0.02-0.002 \mathrm{~mm}$. This research additionally divides fraction $0.02-0.005$ $\mathrm{mm}$ into two sub-fractions, namely: $0.02-0.01 \mathrm{~mm}$ and $0.01-0.005 \mathrm{~mm}$ (Table 1). The fraction was divided due to the high morphological diversity of grains (Table 3 and 4). The morphological parameters of grains have a particularly substantial effect on the bulk density of soil (Photos 1-6).

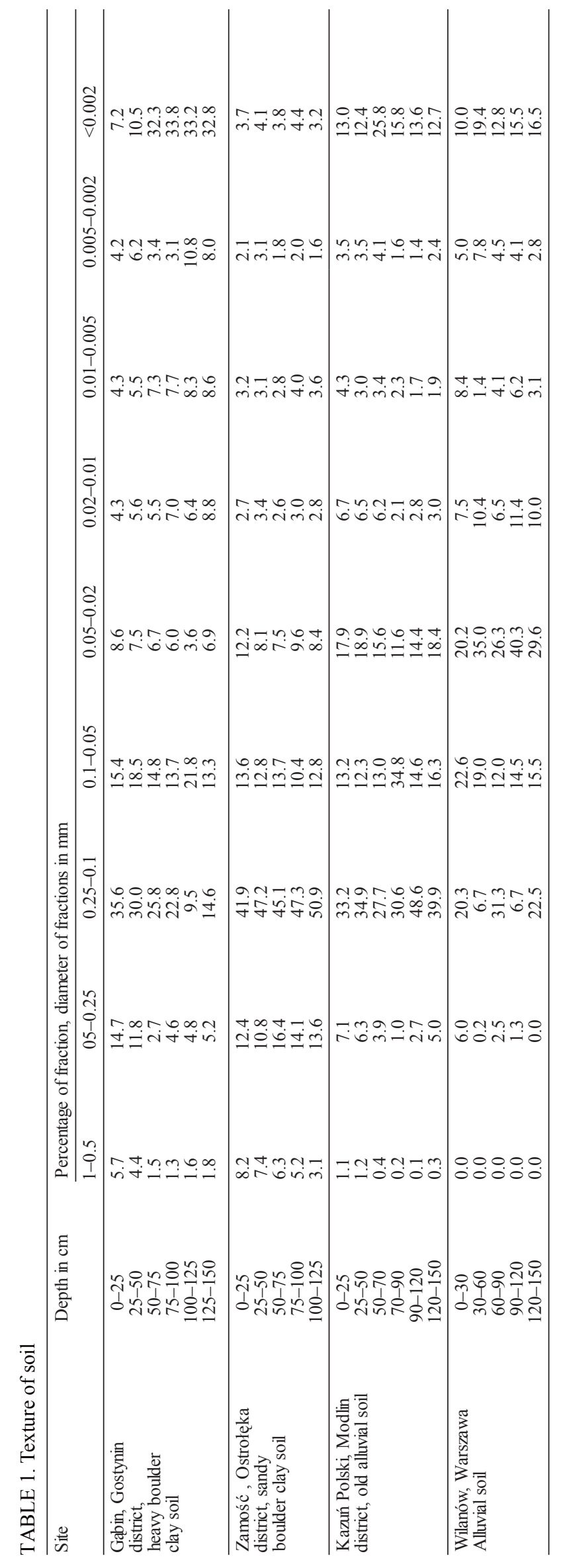


TABLE 2. Particle density of granulometric fractions of soils

\begin{tabular}{|c|c|c|c|c|c|c|c|c|c|c|c|c|}
\hline \multirow{2}{*}{$\begin{array}{l}\text { Location } \\
\text { of profiles }\end{array}$} & \multirow{2}{*}{$\begin{array}{l}\text { Sampling } \\
\text { depth in } \mathrm{cm}\end{array}$} & \multicolumn{9}{|c|}{ Particle density of soil fractions in $\mathrm{g} \cdot \mathrm{cm}^{-3}$, diameter of fractions in $\mathrm{mm}$} & \multicolumn{2}{|l|}{ In whole soil } \\
\hline & & $1-0.5$ & $05-0.25$ & $0.25-0.1$ & $0.1-0.05$ & $0.05-0.02$ & $0.02-0.01$ & $0.01-0.005$ & $0.005-0.002$ & $<0.002$ & determined & calculated \\
\hline Gąbin & $\begin{array}{c}0-25 \\
25-50 \\
50-75 \\
75-100 \\
100-125 \\
125-150\end{array}$ & $\begin{array}{l}2.60 \\
2.59 \\
2.65 \\
2.64 \\
2.63 \\
2.65\end{array}$ & $\begin{array}{l}2.66 \\
2.60 \\
2.60 \\
2.61 \\
2.62 \\
2.63\end{array}$ & $\begin{array}{l}2.64 \\
2.58 \\
2.61 \\
2.62 \\
2.61 \\
2.61\end{array}$ & $\begin{array}{l}2.63 \\
2.63 \\
2.65 \\
2.63 \\
2.64 \\
2.63\end{array}$ & $\begin{array}{l}2.55 \\
2.55 \\
2.65 \\
2.61 \\
2.60 \\
2.61\end{array}$ & $\begin{array}{l}2.52 \\
2.52 \\
2.54 \\
2.60 \\
2.60 \\
2.62\end{array}$ & $\begin{array}{l}2.47 \\
2.46 \\
2.58 \\
2.64 \\
2.60 \\
2.60\end{array}$ & $\begin{array}{l}2.47 \\
2.46 \\
2.58 \\
2.64 \\
2.60 \\
2.60\end{array}$ & $\begin{array}{l}2.37 \\
2.41 \\
2.55 \\
2.60 \\
2.59 \\
2.60\end{array}$ & $\begin{array}{l}2.58 \\
2.60 \\
2.58 \\
2.58 \\
2.60 \\
2.57\end{array}$ & $\begin{array}{l}2.59 \\
2.58 \\
2.58 \\
2.55 \\
2.56 \\
2.47\end{array}$ \\
\hline Zamość & $\begin{array}{c}0-25 \\
25-50 \\
50-75 \\
75-100 \\
100-125\end{array}$ & $\begin{array}{l}2.65 \\
2.66 \\
2.65 \\
2.67 \\
2.67\end{array}$ & $\begin{array}{l}2.64 \\
2.62 \\
2.60 \\
2.64 \\
2.63\end{array}$ & $\begin{array}{l}2.63 \\
2.64 \\
2.61 \\
2.64 \\
2.64\end{array}$ & $\begin{array}{l}2.55 \\
2.51 \\
2.54 \\
2.56 \\
2.52\end{array}$ & $\begin{array}{l}2.50 \\
2.50 \\
2.51 \\
2.52 \\
2.50\end{array}$ & $\begin{array}{l}2.41 \\
2.44 \\
2.48 \\
2.48 \\
2.45\end{array}$ & $\begin{array}{l}2.30 \\
2.32 \\
2.36 \\
2.40 \\
2.40\end{array}$ & $\begin{array}{l}2.27 \\
2.30 \\
2.32 \\
2.32 \\
2.32\end{array}$ & $\begin{array}{l}2.20 \\
2.18 \\
2.35 \\
2.28 \\
2.30\end{array}$ & $\begin{array}{l}2.61 \\
2.61 \\
2.62 \\
2.61 \\
2.57\end{array}$ & $\begin{array}{l}2.58 \\
2.60 \\
2.60 \\
2.58 \\
2.60\end{array}$ \\
\hline Kazuń Polski & $\begin{array}{c}0-25 \\
25-50 \\
50-75 \\
75-100 \\
100-125 \\
125-150\end{array}$ & $\begin{array}{l}2.58 \\
2.62 \\
2.64 \\
2.63 \\
2.64 \\
2.65 \\
\end{array}$ & $\begin{array}{l}2.65 \\
2.66 \\
2.62 \\
2.63 \\
2.64 \\
2.65\end{array}$ & $\begin{array}{l}2.66 \\
2.63 \\
2.65 \\
2.62 \\
2.62 \\
2.64 \\
\end{array}$ & $\begin{array}{l}2.63 \\
2.62 \\
2.61 \\
2.59 \\
2.62 \\
2.65 \\
\end{array}$ & $\begin{array}{l}2.55 \\
2.58 \\
2.60 \\
2.56 \\
2.61 \\
2.64 \\
\end{array}$ & $\begin{array}{l}2.56 \\
2.50 \\
2.60 \\
2.59 \\
2.58 \\
2.61 \\
\end{array}$ & $\begin{array}{l}2.45 \\
2.48 \\
2.44 \\
2.42 \\
2.55 \\
2.55 \\
\end{array}$ & $\begin{array}{l}2.41 \\
2.51 \\
2.51 \\
2.40 \\
2.38 \\
2.52 \\
\end{array}$ & $\begin{array}{l}2.46 \\
2.49 \\
2.45 \\
2.40 \\
2.44 \\
2.42 \\
\end{array}$ & $\begin{array}{l}2.58 \\
2.55 \\
2.56 \\
2.56 \\
2.56 \\
2.60 \\
\end{array}$ & $\begin{array}{l}2.58 \\
2.60 \\
2.50 \\
2.55 \\
2.60 \\
2.60\end{array}$ \\
\hline Wilanów & $\begin{array}{c}0-30 \\
30-60 \\
60-90 \\
90-120 \\
120-150\end{array}$ & $\begin{array}{l}-1 \\
- \\
- \\
- \\
-\end{array}$ & $\begin{array}{l}-1 \\
- \\
- \\
- \\
-\end{array}$ & $\begin{array}{l}2.63 \\
2.58 \\
2.63 \\
2.61 \\
2.62\end{array}$ & $\begin{array}{l}2.58 \\
2.57 \\
2.60 \\
2.59 \\
2.58\end{array}$ & $\begin{array}{l}2.56 \\
2.55 \\
2.57 \\
2.57 \\
2.56\end{array}$ & $\begin{array}{l}2.48 \\
2.53 \\
2.55 \\
2.55 \\
2.56\end{array}$ & $\begin{array}{l}2.46 \\
2.48 \\
2.42 \\
2.48 \\
2.48\end{array}$ & $\begin{array}{l}2.45 \\
2.46 \\
2.42 \\
2.45 \\
2.47\end{array}$ & $\begin{array}{l}2.37 \\
2.39 \\
2.41 \\
2.40 \\
2.42\end{array}$ & $\begin{array}{l}2.60 \\
2.58 \\
2.61 \\
2.57 \\
2.62\end{array}$ & $\begin{array}{l}2.67 \\
2.59 \\
2.62 \\
2.62 \\
2.62\end{array}$ \\
\hline
\end{tabular}

${ }^{1}$ Lack of grains with a diameter of $1-0.5 \mathrm{~mm}$, and trace of grains with a diameter of $0.5-0.25 \mathrm{~mm}$

TABLE 3. Bulk density of granulometric fractions of soils

\begin{tabular}{|c|c|c|c|c|c|c|c|c|c|c|c|c|}
\hline \multirow{2}{*}{$\begin{array}{l}\text { Location } \\
\text { of profiles }\end{array}$} & \multirow{2}{*}{$\begin{array}{l}\text { Sampling } \\
\text { depth in cm }\end{array}$} & \multicolumn{9}{|c|}{ Bulk density of soil fractions in $\mathrm{g} \cdot \mathrm{cm}^{-3}$, diameter of fractions in $\mathrm{mm}$} & \multicolumn{2}{|c|}{ In whole soil } \\
\hline & & $1-0.5$ & $05-0.25$ & $0.25-0.1$ & $0.1-0.05$ & $0.05-0.02$ & $0.02-0.01$ & $0.01-0.005$ & $0.005-0.002$ & $<0.002$ & determined & calculated \\
\hline Gąain & $\begin{array}{c}0-25 \\
25-50 \\
50-75 \\
75-100 \\
100-125 \\
125-150\end{array}$ & $\begin{array}{l}1.54 \\
1.61 \\
1.58 \\
1.60 \\
1.66 \\
1.61\end{array}$ & $\begin{array}{l}1.67 \\
1.64 \\
1.64 \\
1.65 \\
1.60 \\
1.65\end{array}$ & $\begin{array}{l}1.58 \\
1.60 \\
1.65 \\
1.60 \\
1.63 \\
1.58\end{array}$ & $\begin{array}{l}1.46 \\
1.49 \\
1.46 \\
1.53 \\
1.57 \\
1.51\end{array}$ & $\begin{array}{l}1.31 \\
1.36 \\
1.34 \\
1.37 \\
1.43 \\
1.42\end{array}$ & $\begin{array}{l}1.14 \\
1.16 \\
1.19 \\
1.22 \\
1.30 \\
1.35\end{array}$ & $\begin{array}{l}1.00 \\
1.12 \\
1.15 \\
1.21 \\
1.22 \\
1.24\end{array}$ & $\begin{array}{l}1.00 \\
1.00 \\
1.00 \\
1.05 \\
1.15 \\
1.10\end{array}$ & $\begin{array}{l}1.00 \\
1.00 \\
1.11 \\
1.11 \\
1.14 \\
1.11\end{array}$ & $\begin{array}{l}1.50 \\
1.52 \\
1.52 \\
1.60 \\
1.50 \\
1.50\end{array}$ & $\begin{array}{l}1.52 \\
1.46 \\
1.42 \\
1.56 \\
1.39 \\
1.40\end{array}$ \\
\hline Zamośś & $\begin{array}{c}0-25 \\
25-50 \\
50-75 \\
75-100 \\
100-125 \\
\end{array}$ & $\begin{array}{l}1.62 \\
1.71 \\
1.67 \\
1.65 \\
1.70 \\
\end{array}$ & $\begin{array}{l}1.65 \\
1.70 \\
1.68 \\
1.69 \\
1.68 \\
\end{array}$ & $\begin{array}{l}1.66 \\
1.69 \\
1.68 \\
1.70 \\
1.72 \\
\end{array}$ & $\begin{array}{l}1.62 \\
1.64 \\
1.63 \\
1.61 \\
1.63 \\
\end{array}$ & $\begin{array}{l}1.58 \\
1.56 \\
1.54 \\
1.55 \\
1.60 \\
\end{array}$ & $\begin{array}{l}1.41 \\
1.42 \\
1.44 \\
1.46 \\
1.46 \\
\end{array}$ & $\begin{array}{l}1.31 \\
1.34 \\
1.37 \\
1.40 \\
1.40 \\
\end{array}$ & $\begin{array}{l}1.11 \\
1.12 \\
1.16 \\
1.20 \\
1.21 \\
\end{array}$ & $\begin{array}{l}1.10 \\
1.09 \\
1.14 \\
1.20 \\
1.21 \\
\end{array}$ & $\begin{array}{l}1.61 \\
1.65 \\
1.60 \\
1.62 \\
1.60 \\
\end{array}$ & $\begin{array}{l}1.62 \\
1.60 \\
1.62 \\
1.60 \\
1.61 \\
\end{array}$ \\
\hline Kazuń Polski & $\begin{array}{c}0-25 \\
25-50 \\
50-75 \\
75-100 \\
100-125 \\
125-150\end{array}$ & $\begin{array}{l}1.48 \\
1.48 \\
1.50 \\
1.52 \\
1.61 \\
1.62 \\
\end{array}$ & $\begin{array}{l}1.60 \\
1.45 \\
1.48 \\
1.50 \\
1.55 \\
1.66 \\
\end{array}$ & $\begin{array}{l}1.65 \\
1.61 \\
1.55 \\
1.51 \\
1.58 \\
1.60 \\
\end{array}$ & $\begin{array}{l}1.47 \\
1.50 \\
1.44 \\
1.48 \\
1.47 \\
1.51 \\
\end{array}$ & $\begin{array}{l}1.37 \\
1.41 \\
1.40 \\
1.39 \\
1.38 \\
1.39 \\
\end{array}$ & $\begin{array}{l}1.12 \\
1.20 \\
1.16 \\
1.13 \\
1.10 \\
1.12 \\
\end{array}$ & $\begin{array}{l}1.05 \\
1.04 \\
1.05 \\
1.07 \\
1.08 \\
1.11 \\
\end{array}$ & $\begin{array}{l}1.00 \\
1.02 \\
1.00 \\
1.12 \\
1.00 \\
1.00 \\
\end{array}$ & $\begin{array}{l}1.00 \\
1.12 \\
1.28 \\
1.31 \\
1.23 \\
1.32 \\
\end{array}$ & $\begin{array}{l}1.42 \\
1.43 \\
1.38 \\
1.46 \\
1.48 \\
1.42 \\
\end{array}$ & $\begin{array}{l}1.50 \\
1.50 \\
1.45 \\
1.51 \\
1.54 \\
1.46 \\
\end{array}$ \\
\hline Wilanów & $\begin{array}{c}0-30 \\
30-60 \\
60-90 \\
90-120 \\
120-150\end{array}$ & $\begin{array}{l}-1 \\
- \\
- \\
- \\
-\end{array}$ & $\begin{array}{l}{ }^{1} \\
- \\
- \\
- \\
-\end{array}$ & $\begin{array}{l}1.52 \\
1.61 \\
1.61 \\
1.66 \\
1.67\end{array}$ & $\begin{array}{l}1.50 \\
1.51 \\
1.51 \\
1.51 \\
1.52\end{array}$ & $\begin{array}{l}1.44 \\
1.48 \\
1.48 \\
1.46 \\
1.48\end{array}$ & $\begin{array}{l}1.16 \\
1.15 \\
1.22 \\
1.18 \\
1.31\end{array}$ & $\begin{array}{l}1.11 \\
1.11 \\
1.12 \\
1.19 \\
1.20\end{array}$ & $\begin{array}{l}1.06 \\
1.08 \\
1.09 \\
1.10 \\
1.13\end{array}$ & $\begin{array}{l}1.00 \\
1.00 \\
1.04 \\
1.08 \\
1.08\end{array}$ & $\begin{array}{l}1.50 \\
1.44 \\
1.40 \\
1.37 \\
1.47\end{array}$ & $\begin{array}{l}1.48 \\
1.43 \\
1.48 \\
1.42 \\
1.43\end{array}$ \\
\hline
\end{tabular}


TABLE 4. Total porosity of separate granulometric fractions of soil

\begin{tabular}{|c|c|c|c|c|c|c|c|c|c|c|c|c|}
\hline \multirow[t]{2}{*}{ Site } & \multirow{2}{*}{$\begin{array}{l}\text { Sampling } \\
\text { depth in cm }\end{array}$} & \multicolumn{9}{|c|}{ Total porosity of soil fractions in $\mathrm{g} \mathrm{cm}^{-3}$, diameter of fractions in $\mathrm{mm}$} & \multicolumn{2}{|c|}{ In whole soil } \\
\hline & & $1-0.5$ & $05-0.25$ & $0.25-0.1$ & $0.1-0.05$ & $0.05-0.02$ & $0.02-0.01$ & $0.01-0.005$ & $0.005-0.002$ & $<0.002$ & determined & calculated \\
\hline Gabin & $\begin{array}{c}0-25 \\
25-50 \\
50-75 \\
75-100 \\
100-125 \\
125-150\end{array}$ & $\begin{array}{l}40.8 \\
37.8 \\
40.4 \\
39.4 \\
36.9 \\
39.2\end{array}$ & $\begin{array}{l}37.2 \\
36.9 \\
36.9 \\
36.4 \\
38.9 \\
37.3\end{array}$ & $\begin{array}{l}40.0 \\
38.0 \\
36.8 \\
38.9 \\
37.5 \\
39.5\end{array}$ & $\begin{array}{l}44.5 \\
43.3 \\
44.9 \\
41.8 \\
40.5 \\
42.6\end{array}$ & $\begin{array}{l}48.6 \\
46.7 \\
49.4 \\
47.5 \\
45.0 \\
45.6\end{array}$ & $\begin{array}{l}54.8 \\
54.0 \\
53.1 \\
53.1 \\
50.0 \\
48.5\end{array}$ & $\begin{array}{l}59.5 \\
55.0 \\
55.4 \\
54.2 \\
53.4 \\
53.0\end{array}$ & $\begin{array}{l}59.5 \\
59.3 \\
61.2 \\
60.2 \\
55.8 \\
57.7\end{array}$ & $\begin{array}{l}57.8 \\
58.5 \\
56.5 \\
57.3 \\
56.0 \\
57.3\end{array}$ & $\begin{array}{l}41.8 \\
39.6 \\
39.9 \\
38.0 \\
39.6 \\
40.8\end{array}$ & $\begin{array}{l}41.3 \\
45.4 \\
45.0 \\
38.8 \\
47.6 \\
45.5\end{array}$ \\
\hline Zamość & $\begin{array}{c}0-25 \\
25-50 \\
50-75 \\
75-100 \\
100-125 \\
\end{array}$ & $\begin{array}{l}38.8 \\
35.7 \\
37.0 \\
38.2 \\
36.3 \\
\end{array}$ & $\begin{array}{l}37.5 \\
35.1 \\
35.4 \\
36.0 \\
36.1 \\
\end{array}$ & $\begin{array}{l}36.9 \\
36.0 \\
35.6 \\
35.6 \\
34.8 \\
\end{array}$ & $\begin{array}{l}36.5 \\
34.7 \\
35.8 \\
37.1 \\
35.2 \\
\end{array}$ & $\begin{array}{l}36.8 \\
37.6 \\
38.6 \\
38.7 \\
36.0 \\
\end{array}$ & $\begin{array}{l}41.5 \\
41.8 \\
41.9 \\
41.1 \\
40.4 \\
\end{array}$ & $\begin{array}{l}43.0 \\
42.2 \\
41.9 \\
41.7 \\
41.7 \\
\end{array}$ & $\begin{array}{l}51.1 \\
51.3 \\
50.0 \\
48.3 \\
47.8 \\
\end{array}$ & $\begin{array}{l}50.0 \\
50.0 \\
51.5 \\
47.4 \\
47.4 \\
\end{array}$ & $\begin{array}{l}39.3 \\
36.8 \\
38.0 \\
37.9 \\
37.7 \\
\end{array}$ & $\begin{array}{l}37.2 \\
38.5 \\
37.7 \\
38.0 \\
38.1 \\
\end{array}$ \\
\hline Kazuń Polski & $\begin{array}{c}5-30 \\
30-50 \\
50-70 \\
70-90 \\
90-120 \\
120-150 \\
\end{array}$ & $\begin{array}{l}42.6 \\
43.5 \\
43.2 \\
42.2 \\
39.0 \\
38.8 \\
\end{array}$ & $\begin{array}{l}39.6 \\
45.5 \\
43.5 \\
43.0 \\
41.3 \\
37.5 \\
\end{array}$ & $\begin{array}{l}38.0 \\
38.8 \\
41.5 \\
42.4 \\
39.7 \\
39.4 \\
\end{array}$ & $\begin{array}{l}44.1 \\
42.7 \\
44.8 \\
42.8 \\
43.9 \\
43.0 \\
\end{array}$ & $\begin{array}{l}46.3 \\
45.3 \\
46.8 \\
45.7 \\
47.1 \\
47.3 \\
\end{array}$ & $\begin{array}{l}56.2 \\
52.0 \\
55.4 \\
56.4 \\
57.4 \\
57.1 \\
\end{array}$ & $\begin{array}{l}57.1 \\
58.0 \\
57.0 \\
55.8 \\
57.6 \\
56.5 \\
\end{array}$ & $\begin{array}{l}58.5 \\
59.4 \\
60.1 \\
49.2 \\
57.9 \\
58.0 \\
\end{array}$ & $\begin{array}{l}59.3 \\
55.0 \\
47.8 \\
41.3 \\
49.6 \\
45.5 \\
\end{array}$ & $\begin{array}{l}46.5 \\
45.1 \\
46.9 \\
44.9 \\
49.6 \\
45.5 \\
\end{array}$ & $\begin{array}{l}41.9 \\
42.3 \\
46.0 \\
40.8 \\
40.8 \\
43.8 \\
\end{array}$ \\
\hline Wilanów & $\begin{array}{c}0-30 \\
30-60 \\
60-90 \\
90-120 \\
120-150\end{array}$ & $\begin{array}{l}-^{1} \\
- \\
- \\
- \\
-\end{array}$ & $\begin{array}{l}-^{1} \\
- \\
- \\
- \\
-\end{array}$ & $\begin{array}{l}42.2 \\
37.6 \\
38.8 \\
36.4 \\
36.3\end{array}$ & $\begin{array}{l}41.8 \\
41.2 \\
41.9 \\
41.7 \\
41.1\end{array}$ & $\begin{array}{l}43.7 \\
42.0 \\
42.4 \\
43.2 \\
42.2\end{array}$ & $\begin{array}{l}53.2 \\
54.5 \\
52.1 \\
53.7 \\
48.8\end{array}$ & $\begin{array}{l}54.9 \\
55.2 \\
53.7 \\
52.0 \\
51.6\end{array}$ & $\begin{array}{l}56.7 \\
65.1 \\
54.9 \\
55.1 \\
54.2\end{array}$ & $\begin{array}{l}58.0 \\
58.1 \\
55.8 \\
55.0 \\
55.4\end{array}$ & $\begin{array}{l}42.3 \\
44.2 \\
46.4 \\
46.7 \\
43.9\end{array}$ & $\begin{array}{l}44.6 \\
44.8 \\
43.5 \\
45.8 \\
45.4\end{array}$ \\
\hline
\end{tabular}

${ }^{1}$ Lack of grains with a diameter of $1-0.5 \mathrm{~mm}$, and trace of grains with a diameter of $0.5-0.25 \mathrm{~mm}$
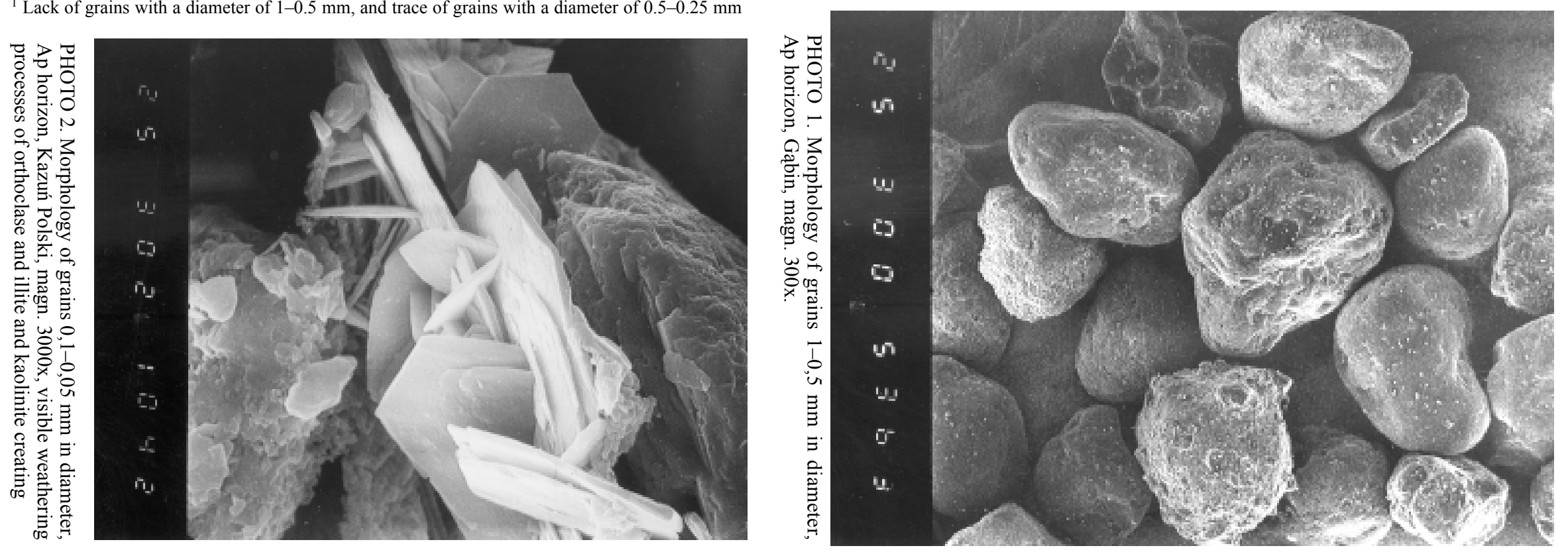


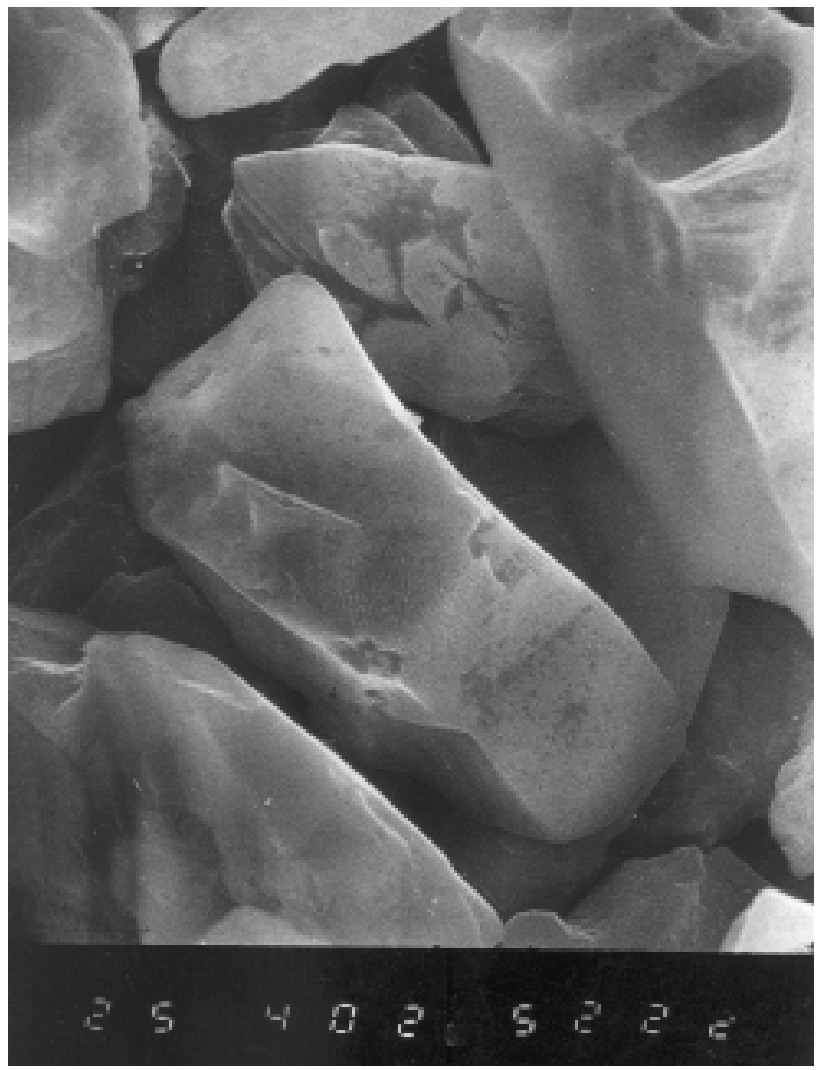

PHOTO 3. Morphology of grains $0,02-0,01 \mathrm{~mm}$ in diameter, $\mathrm{C}$ horizon, $75-100 \mathrm{~cm}$, Gąbin, magn. 4000x

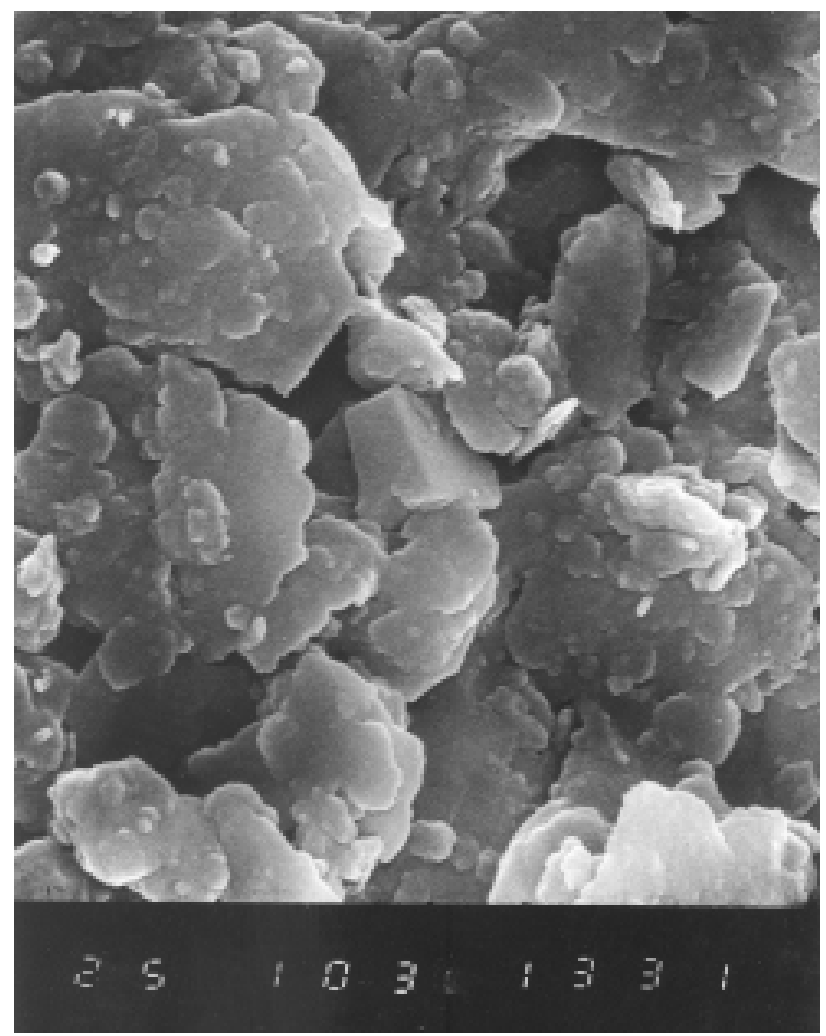

PHOTO 4. Morphology of grains $0,005-0,002 \mathrm{~mm}$ in diameter, $\mathrm{C}$ horizon, Gąbin, magn. 10 000x

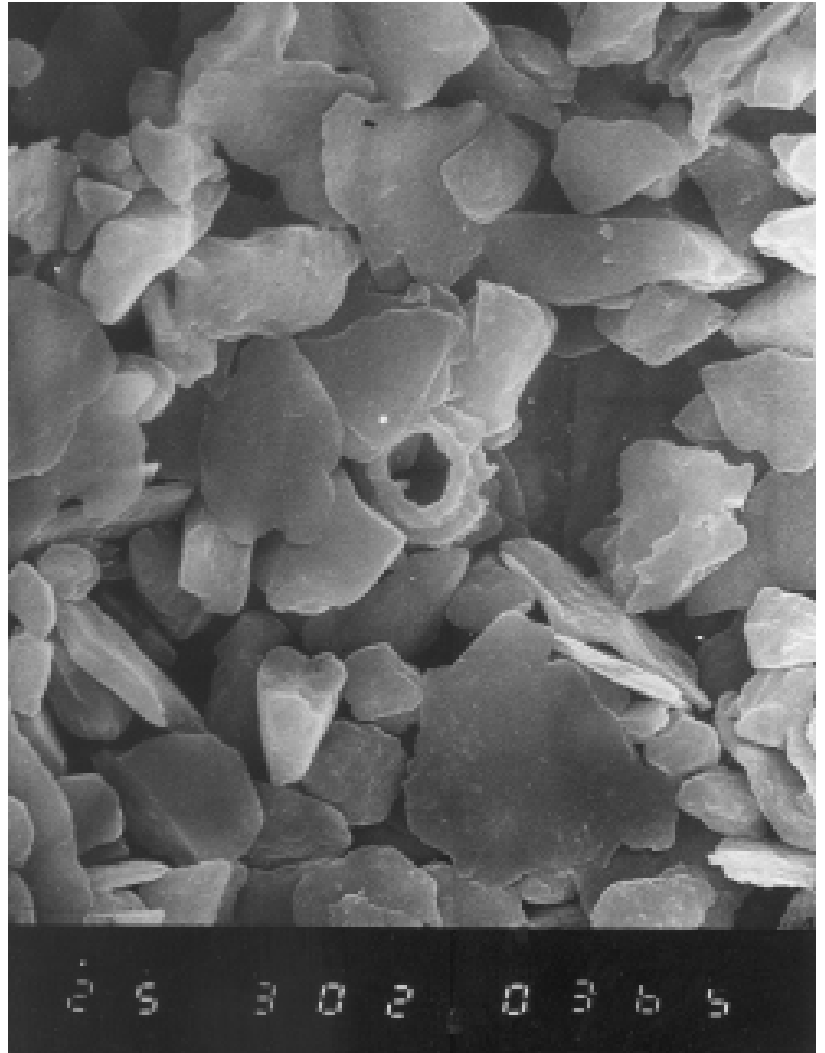

PHOTO 5. Morphology of grains $<0,002 \mathrm{~mm}$ in diameter, C horizon, $70-90 \mathrm{~cm}$. Kazuń Polski, magn. 3000x. In centrum of phot. visible mineral from zeolitic group - chabasite

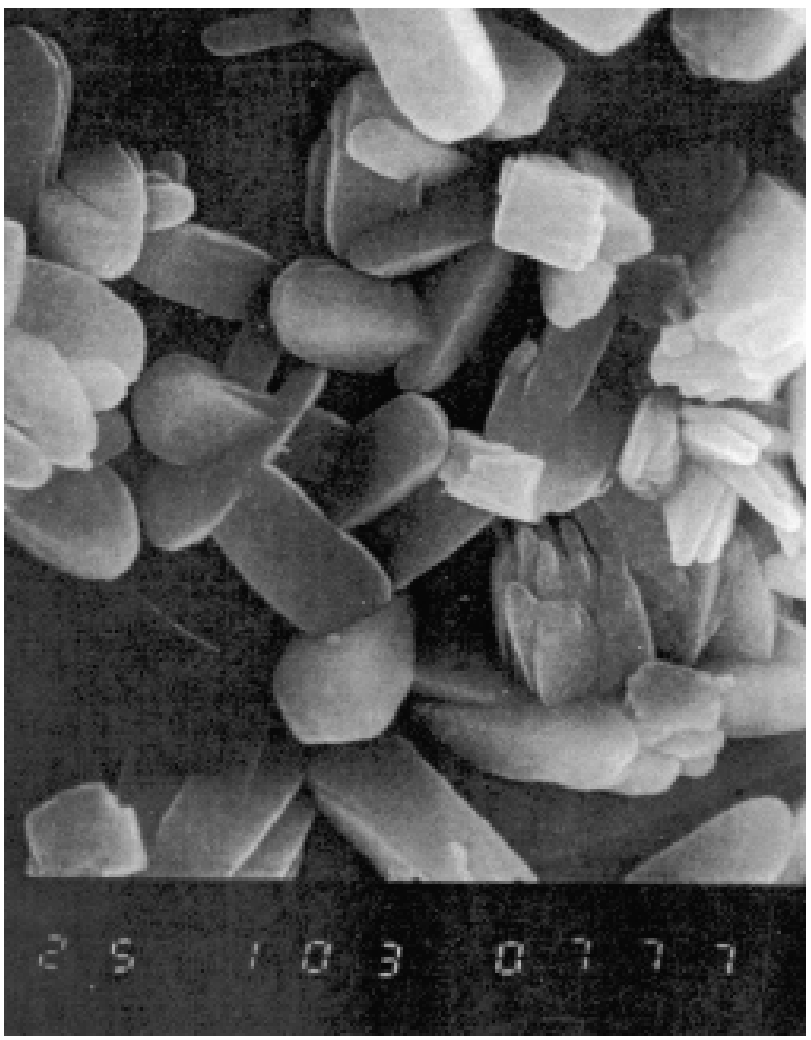

PHOTO 6. Morphology of grains $<0,002 \mathrm{~mm}$ in diameter, C horizon 70-90 cm. Kazuń Polski magn. 10 000x. Porous structure of the zeolite phillipsite 


\section{Particle density of granulometric fractions of soils}

The particle density of granulometric fractions depends exclusively on the mineralogical composition of the soil material and content of organic matter in the grains. The particle density of the analysed fractions decreases from grains with a diameter of $1.0-0.1 \mathrm{~mm}$ to clay grains $<0.002 \mathrm{~mm}$. This is related to a gradual change in the mineralogical composition. Moreover, along with a decrease in the diameter of fractions, the content of organic matter in them increases, with the average particle density of approximately $1.4 \mathrm{~g} \cdot \mathrm{cm}^{-3}$.

Particle density of soil grains with a diameter of 1-0.02 mm. In Polish geomorphological conditions, soil grains with a diameter of $1-0.02 \mathrm{~mm}$ are predominantly composed of quartz $\mathrm{SiO}_{2}$ with a density of $2.65 \mathrm{~g} \cdot \mathrm{cm}^{-3}$ with a slight addition of other primary minerals (e.g. feldspars) with similar density. Moreover, the composition of this group of grains includes scarce amounts of organic remains humified to a low degree. Therefore, a decrease in the diameter of fractions is accompanied by an increase in the content of organic matter. As a result, the particle density gradually and very inconsiderably decreases in the fractions.

A mean particle density of fraction $1-0.1 \mathrm{~mm}$ determined for all of the soils and their horizons amounts to $2.63 \mathrm{~g} \cdot \mathrm{cm}^{-3}$ with extreme variations from 2.58 to $2.67 \mathrm{~g} \cdot \mathrm{cm}^{-3}$ (Table 2). The mean particle density of the fraction with a diameter of $0.1-0.02 \mathrm{~mm}$ amounts to $2.57 \mathrm{~g} \cdot \mathrm{cm}^{-3}$, varying from 2.51 to $2.65 \mathrm{~g} \cdot \mathrm{cm}^{-3}$. A slight decrease in the density of the fraction with a diameter of $0.1-0.02 \mathrm{~mm}$ in relation to grains with a diameter of $1-0.1 \mathrm{~mm}$ amounts to an average of only $2.1 \%$, and is approximately proportionate to an increase in the content of organic compounds. Moreover, in grains with a diameter of $0.1-0.02 \mathrm{~mm}$, the chemical weathering process is evident, as well as the development of new minerals with lower density varying from 2.57 to $2.60 \mathrm{~g} \cdot \mathrm{cm}^{-3}$ (Photo 2) was confirmed. The photograph shows a clear structure of illite and a hexagonal kaolinite crystal, as well as feldspar weathering into those two secondary minerals.

Particle density in the sub-group of fractions with a diameter of $0.02-0.01 \mathrm{~mm}$ is similar to that of the fraction with a diameter of $0.05-0.02 \mathrm{~mm}$, except for sandy soil (Zamość). Fractions with a diameter of $0.02-0.01 \mathrm{~mm}$ extracted from sandy soil show considerably lower specific density than the remaining soils. This results from a considerably higher abundance of humic compounds in these fractions in comparison to fractions with the same diameter in the others soils studied.

Fractions with a diameter of $0.01-0.002 \mathrm{~mm}$ are distinguished by particle density lower than that of fraction $>0.01 \mathrm{~mm}$. The fractions extracted from particular soils show relatively high variability (Fig. 1) in comparison to fractions with a larger diameter. This results from the varied content of humic compounds as well as the mineralogical composition. In fractions with a diameter of $<0.01 \mathrm{~mm}$, the content of quartz considerably decreases, and the content of opal silica $\mathrm{SiO}_{2} \cdot \mathrm{nH}_{2} \mathrm{O}$ with a density of $1.9-2.4 \mathrm{~g} \cdot \mathrm{cm}^{-3}$ and illite with a density of $2.56 \mathrm{~g} \cdot \mathrm{cm}^{-3}$, as well as various variations of montmorillonite with a density of 1.80 $2.55 \mathrm{~g} \cdot \mathrm{cm}^{-3}$ increases. The content of humic compounds particularly increases up to several percent. The highest particle densities of fractions with a diameter of $0.01-0.002 \mathrm{~mm}$ are reached in the case of grains of soil developed from boulder clay (Gabin), and the lowest from loamy sand (Zamość) (Table 2).

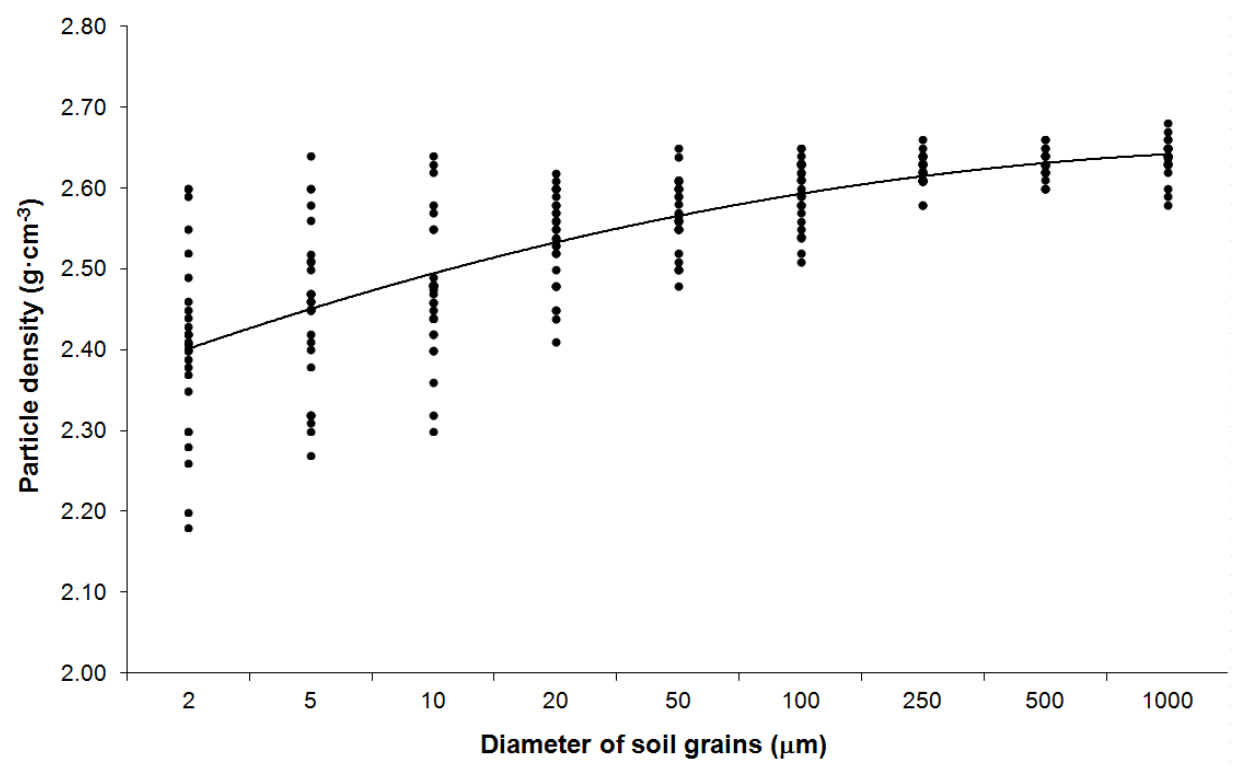

FIGURE 1. Particle density of granulometric fractions of soil 
The clay fraction of the analysed soils $(<0.002 \mathrm{~mm})$ shows the lowest particle density among all of the soil fractions. The fraction is composed of varied clay materials (Brogowski and Mazurek 1981, 1990) and high content of humic compounds. The mean particle density of the clay fraction of the analysed soils amounts to $2.40 \mathrm{~g} \cdot \mathrm{cm}^{-3}$, with individual values varying from $2.18 \mathrm{~g} \cdot \mathrm{cm}^{-3}$ in sandy soil to $2.60 \mathrm{~g} \cdot \mathrm{cm}^{-3}$ in soil developed from heavy boulder clay (Table 2). The density of the fraction in comparison to the fraction with a diameter of $1-0.1 \mathrm{~mm}$ is lower by $8.9 \%$ on the average, with values for the analysed soils varying from 1.1 to $17.1 \%$. This is related to the mineralogical composition (Brogowski and Mazurek 1981; Brogowski 1990) and content of organic matter in this group of fractions (Okołowicz and Brogowski 1996).

Due to the high stability of particle density of particular groups of granulometric fractions, coefficients were developed for the calculation of this property of soils based on the texture, with no need to perform strenuous determinations of soil density. The coefficients developed before (Brogowski 1990) were verified in this paper based on more extensive research material (Uziak et al. 2005). An example of calculation of specific density is provided in the "Materials and methods" section.

\section{Bulk density of granulometric fractions of soils}

The bulk density of both whole soil and separate granulometric fractions depends on a number of factors. The factors include among others the mineral composition, content of organic matter, morphology and size of soil grains, spatial distribution of grains and aggregates, etc. (Photos 1-6).
Fraction $1-0.1 \mathrm{~mm}$, due to the round shapes and large diameter, shows the highest bulk density value (Table 3 and Photo 1). The mean bulk density of the fraction of all of the analysed soils amounts to $1.62 \mathrm{~g} \cdot \mathrm{cm}^{-3}$ for individual values varying from 1.48 to $1.72 \mathrm{~g} \cdot \mathrm{cm}^{-3}$ (Fig. 2). The highest bulk density occurs in the case of sand fractions extracted from sandy soil, and the lowest from the soil of the old terrace of the Vistula River. The density of the fraction usually slightly and gradually increases down the soil profiles. This may result from a decreasing content of organic matter down the soil profiles.

Fraction $0.1-0.02 \mathrm{~mm}$ shows considerably lower bulk density, resulting from its specific morphology. As a result of weathering, scarce grains composed of feldspars develop relatively complex shapes composed of clay minerals - illite and kaolinite (Photo 2). The mean density of the fraction from all of the analysed soils amounts to $1.49 \mathrm{~g} \cdot \mathrm{cm}^{-3}$ for individual values

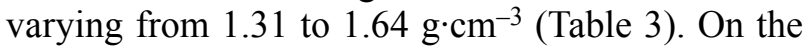
average, it is lower than that of sand grains by $8.1 \%$.

Fraction $0.02-0.002 \mathrm{~mm}$ has a specific morphological structure, showing bulk density considerably lower than that of the fractions discussed above. In this group of fractions, a substantial decrease in bulk density occurs from fraction with a diameter of 0.02 $0.01 \mathrm{~mm}$, with the mean density from all of the analysed soils amounting to $1.25 \mathrm{~g} \cdot \mathrm{cm}^{-3}$, to fraction with a diameter of 0.005-0.002 with mean density of only $1.08 \mathrm{~g} \cdot \mathrm{cm}^{-3}$ (Fig. 2, Photo 3 and 4). The fraction shows the lowest density, lower than that of fraction $<0.002$ $\mathrm{mm}$. This results from its mineralogical composition. The predominant clay mineral in the fraction is illite (Brogowski and Mazurek 1990). The mineral is composed of plates developing a specific "card ho-
FIGURE 2. Bulk density of granulometric fractions of soils

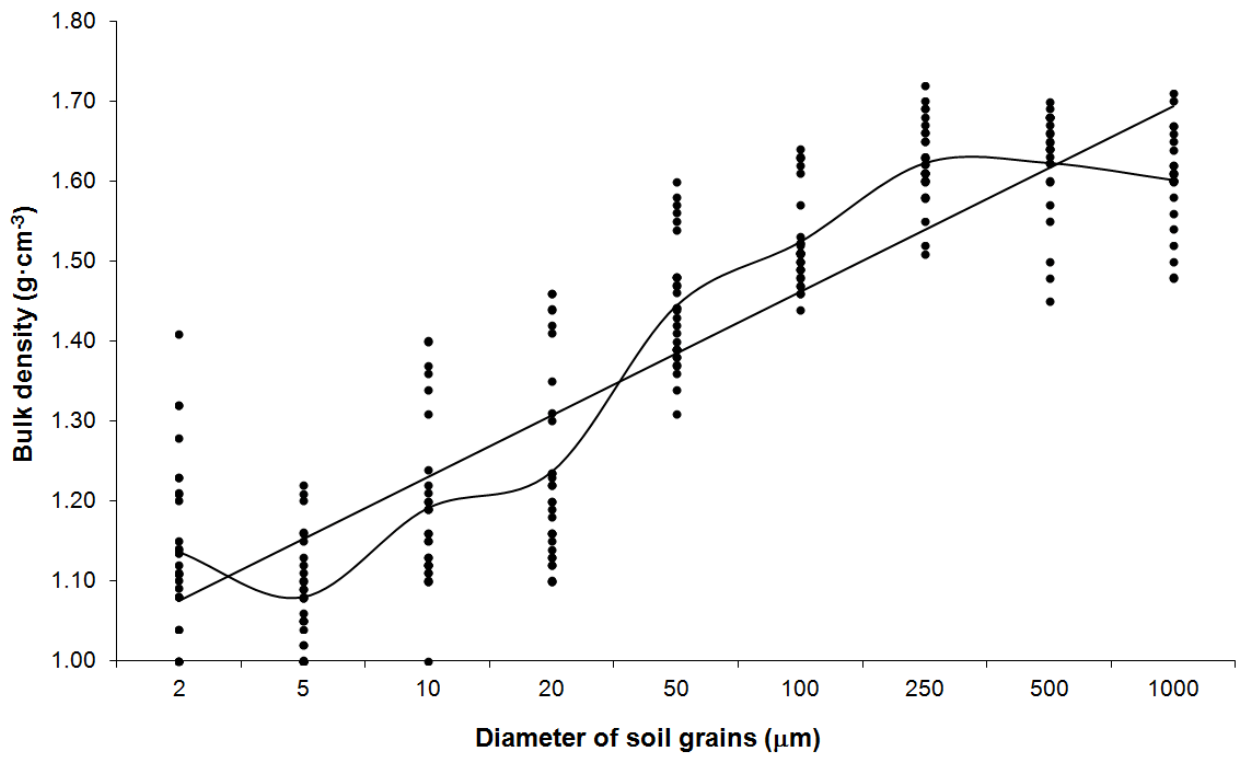




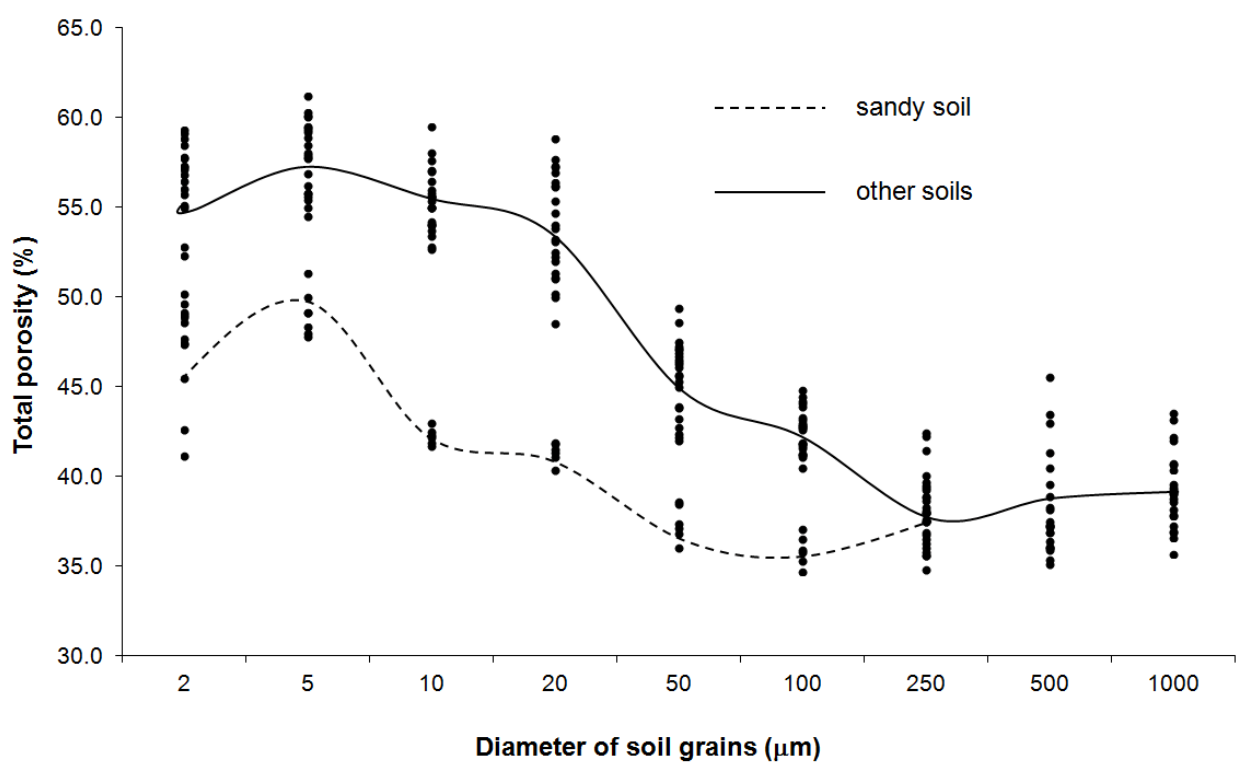

FIGURE 3. Total porosity of the separate granulometric fractions of the soils
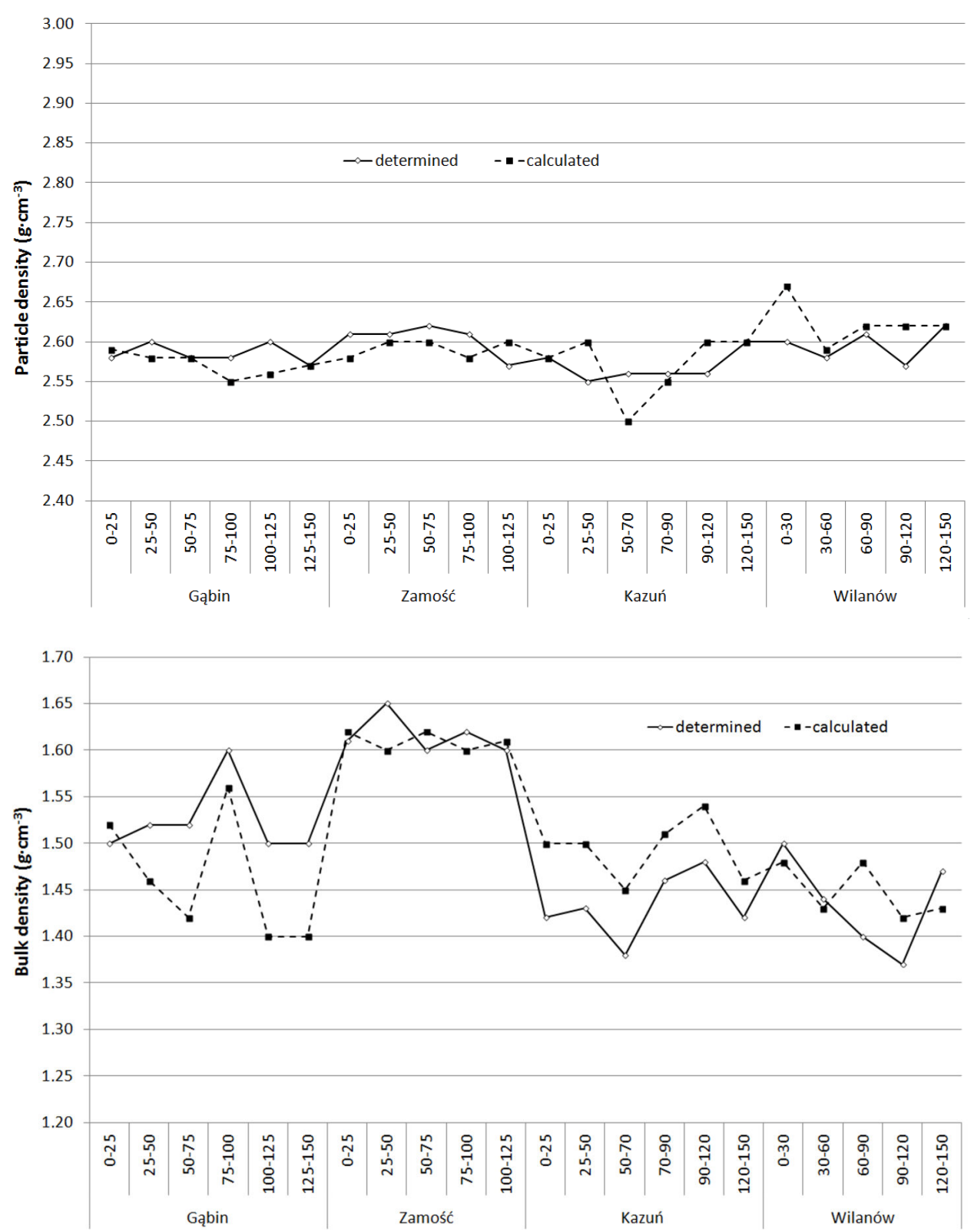

FIGURE 4. Comparison of particle densities of soil determined by picnometric method and calculated using the soil texture data

FIGURE 5. Comparison of bulk densities of soil determined by traditional method and calculated using the soil texture data 
FIGURE 6. Comparison of the total porosity of soils calculated by the traditional method and calculated using the soil texture data

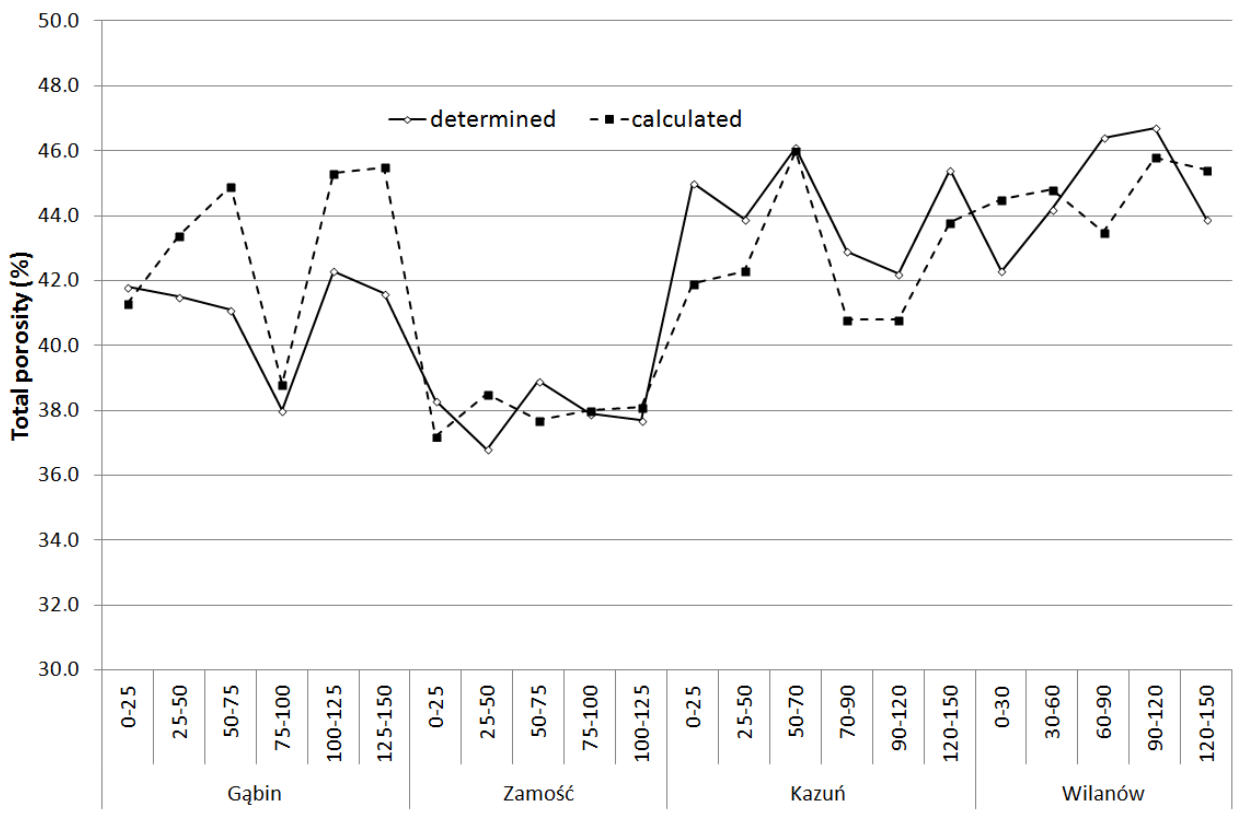

use" with low bulk density and high porosity. The mean bulk density of the fraction with a diameter of 0.02 $0.002 \mathrm{~mm}$ is lower than the density of sand grains by $27.5 \%$, with values for particular groups of grains varying from 22.8 to $33.3 \%$. Such a considerable decrease in bulk density of these groups of fractions is related to the morphology of the grains.

Fraction $<0.002 \mathrm{~mm}$ is predominantly composed of loamy minerals with a specific morphological structure and considerable content of organic matter. In spite of this, it shows higher bulk density than the fraction with a diameter of $0.005-0.002 \mathrm{~mm}$. This may result from the difference in the mineral composition of the fractions. In Polish geographical-geological conditions, fraction $0.005-0.002 \mathrm{~mm}$ is predominantly composed of illite and kaolinite - minerals with platy structure. Clay fraction $<0.002 \mathrm{~mm}$ is particularly composed of minerals with a relatively loose structure, easier to pack in a volume unit. Only in scarce cases, minerals with "reticular" structures may occur in the fraction (Photo 6), composed of philipsite from the group of zeolites. The bulk density of fraction $<0.002 \mathrm{~mm}$ varies in particular soils and genetic horizons from 1.0 to $1.32 \mathrm{~g} \cdot \mathrm{cm}^{-3}$, with the mean value amounting to $1.11 \mathrm{~g} \cdot \mathrm{cm}^{-3}$. The value is lower than the density of sand grains by $31.5 \%$.

Due to a certain level of stability of bulk density in particular groups of fractions, coefficients were developed permitting the calculation of this parameter based on the accurately determined texture (Table 5). The calculation of bulk density is performed by means of a method similar to that for calculating particle density, only using coefficients adopted for this density (Table 5).
TABLE 5. Coefficients for the calculation of specific density, bulk density, and total porosity of soil based on texture

\begin{tabular}{lllll}
\hline \begin{tabular}{l} 
Grain diameter $\begin{array}{l}\text { Coefficients } \\
\text { in mm }\end{array}$ \\
\cline { 2 - 5 }
\end{tabular} & $\begin{array}{l}\text { lor calculation of specific } \\
\text { density }\end{array}$ & $\begin{array}{l}\text { for calcula- } \\
\text { tion of bulk } \\
\text { density }\end{array}$ & $\begin{array}{l}\text { for calcula- } \\
\text { tion of total } \\
\text { porosity }\end{array}$ \\
\cline { 2 - 5 } & $\begin{array}{l}\text { in silty } \\
\text { soils }\end{array}$ & in other soils & & \\
\hline $1-0.5$ & 0.0275 & 0.0275 & 0.0184 & 0.330 \\
$0.5-0.25$ & 0.0270 & 0.0270 & 0.0176 & 0.348 \\
$0.25-0.1$ & 0.0265 & 0.0265 & 0.0167 & 0.370 \\
$0.1-0.05$ & 0.0270 & 0.0260 & 0.0156 & 0.345 \\
$0.05-0.02$ & 0.0280 & 0.0250 & 0.0150 & 0.412 \\
$0.02-0.005$ & 0.0245 & 0.0245 & 0.0132 & 0.456 \\
$0.005-0.002$ & 0.0235 & 0.0235 & 0.0125 & 0.490 \\
$<0.002$ & 0.0232 & 0.0232 & 0.0117 & 0.520 \\
\hline
\end{tabular}

Total porosity in granulometric fractions of soils

This property results from the two discussed densities: particle density and bulk density. Values of these parameters decrease along with a decrease in the diameter of soil grains. As a consequence, total porosity increases gradually along a decrease in the diameter of grains (Table 3 and Fig. 3).

Fraction $1.0-0.1 \mathrm{~mm}$ shows the lowest porosity, rarely exceeding $40 \%$ (Table 4 ). The mean porosity of all of the analysed sand fractions from four profiles amounts to $38.5 \%$, with individual values varying from 35.1 to $45.5 \%$ (Table 4 ). The highest total porosity occurs in the case of sand grains extracted from the formation of the old terrace of the Vistula River, and the lowest from boulder sand.

Fraction $0.1-0.02 \mathrm{~mm}$ shows slightly higher porosity in comparison with sand grains. The mean increase in porosity of the fraction is higher than in the case of the sand fraction by $9.6 \%$. No impact of 
genetic horizons or grain structure of the soil material on the degree of porosity is observed in this fraction, except for the soil profile developed from sand (Fig. 3). Fractions $<0.1 \mathrm{~mm}$ extracted from sandy soil show considerably lower porosity than the same fractions extracted from soils with heavier texture.

Fraction $0.02-0.002 \mathrm{~mm}$ shows a further gradual increase in total porosity along with a decrease in the diameter of the analysed grains (Table 4, Fig. 2). The fractions show evident variability of porosity depending on the texture of soils, similarly as in fractions $0.1-0.02 \mathrm{~mm}$ (Fig. 3). Mean porosities for the fraction with a diameter of $0.02-0.01 \mathrm{~mm}$ amount to $50.4 \%$, for fraction $0.01-0.005 \mathrm{~mm} 51.9 \%$, and for fraction $0.005-$ $0.002 \mathrm{~mm} 55.3 \%$. The mean value for all of the fractions in a range of $0.02-0.002 \mathrm{~mm}$ amounts to $52.5 \%$ (Table 4 and Fig. 3).

Fraction $<0.002 \mathrm{~mm}$ shows somehow higher total porosity than the fraction with a diameter of $0.005-0.002 \mathrm{~mm}$ (Table 4 and Fig. 3). The mean porosity of the fraction for all of the analysed soils amounts to $53.2 \%$, with individual values varying from 41.3 to $58.5 \%$, whereas the mean porosity of fraction $0.005-0.002 \mathrm{~mm}$ amounts to $55.3 \%$. The differences are inconsiderable, but show an evident impact of the diverse composition of clay minerals on the physical state of the fraction, and indirectly also on the soils. Fractions $0.005-0.002$ $\mathrm{mm}$ usually show the predominance of minerals from the group of illites, and fractions $<0.002 \mathrm{~mm}$ minerals from the group of montomorilonite (Brogowski and Mazurek 1981). The minerals vary in terms of grain morphology and are therefore varied in terms of density and porosity.

In relation to the determined correlation between fraction diameter and total porosity, coefficients were also developed permitting direct calculation of total porosity with the avoidance of the determination of densities (Table 5). Total porosity can be calculated from the determined particle and bulk density, or with the application of coefficients presented in Table 5. The calculation is performed similarly as in the example provided in the methodology section.

\section{DISCUSSION}

The study evidenced that particle density and bulk density of separate granulometric fractions of various types of soils is to a certain degree correlated with their diameter (Fig. 1 and 2). The correlation was used in the study for the development of coefficients for each of the fractions permitting the calculation of both particle density and bulk density of soil (Table 2 and 3) (Brogowski 1990). The determination of these two values provides the basis for calculating the total porosity of soil. Based on the density results, coefficients were also developed for the direct calculation of total porosity from the texture with the avoidance of calculating particle and bulk density (Table 5).

The extensive material concerning research on fractions of Polish mountainous soils and soils developed from loesses (Uziak et al. 2005) provided the basis for concluding that the coefficients for the calculation of density and porosity developed before cannot be applied in the case of these loess soils. Therefore, following the verification, separate coefficients were introduced for this group of soils (Table 5). It should also be emphasised that the coefficients are not applicable to tropical soils. The determinations for chestnut soil (Kastanozem) from Thailand show completely different densities for particular fractions and whole soil. The particle density of such soils does not exceed $2.2 \mathrm{~g} \cdot \mathrm{cm}^{-3}$, and the bulk density $1.2 \mathrm{~g} \cdot \mathrm{cm}^{-3}$ (the results are not shown in this study). This results from a different mineralogical composition. The soils may contain gibbsite $\mathrm{Al}(\mathrm{OH})_{3}$ with a density of $2.35 \mathrm{~g} \cdot \mathrm{cm}^{-3}$ and opal $-\mathrm{SiO}_{2} \cdot \mathrm{nH}_{2} \mathrm{O}$ with a density depending on the number of particles of bound water, varying from 1.90 to $2.5 \mathrm{~g} \cdot \mathrm{cm}^{-3}$ (the maximum number of water particles in opal amounts to 5 , which constitutes $34 \%$ of water in the mineral). Moreover, soils of the type developed from basalt may contain minerals from the group of zeolites with a mean density of $2.2 \mathrm{~g} \cdot \mathrm{cm}^{-3}$.

The results of the comparative research concerning the density of whole soils and calculated from the developed coefficients are very similar (Tables $2-4$, Fig. 4-6). The highest level of similarity concerns results of particle density (Fig. 4). The variability coefficient does not exceed 5.3\%. Somewhat higher differences occur between the determinations and calculations concerning bulk density (Table 3 and Fig. 2), and therefore also porosity (Table 3 and 4, Fig. 5 and 6). The variability coefficients do not exceed $11.5 \%$. In the case of the determination of bulk density by means of the traditional method, substantial differences also occur. Inaccuracies in the determination of bulk density of soil result from sampling soil in the field by means of cylinders with a particular volume.

It should be emphasised that the developed coefficients for the calculations of the discussed physical parameters based exclusively on texture will largely facilitate more extensive physical description of soils with no relatively strenuous field and laboratory research.

We kindly request anyone using the developed coefficients, as well as persons conducting research by means of traditional methods, to submit any comments regarding the achievements of our method. We would like to thank you in advance for sending your 
comments to the address of the Department of Soil Environment Sciences of the University of Life Sciences in Warsaw.

\section{CONCLUSIONS}

1. The particle density and bulk density of particular granulometric fractions of soils decrease with a decrease in their diameter.

2. The total porosity of granulometric fractions of soils gradually increases along a decrease in their diameter.

3. The verified and supplemented coefficients for the calculation of particle density, bulk density, and total porosity based on soil texture permit obtaining credible results within the range of analytical errors.

4. The proposed calculations of density and total porosity of soils are applicable to the general description of soils. They cannot, however, replace exact scientific research on the physical state of soils.

5. The discussed properties of granulometric fractions (particle density, bulk density, and total porosity) depend on the mineral composition, grain morphology, and content of organic matter.

\section{REFERENCES}

Arvidsson J., 1998. Influence of soil texture and organic matter content on bulk density, air content, compression index and crop yield in field and laboratory compression experiment. Soil and Tillage Research, 49: 159-170.

Brogowski Z., 1990: Próba obliczenia niektórych właściwości fizycznych gleb na podstawie analizy ziarnowej (Attempt to calculate certain physical parameters of soils based on the granulometric analysis). Roczniki Gleboznawcze - Soil Science Annual, 31(3-4): 17-28. (in Polish)

Brogowski Z., Mazurek A., 1981. Differentiation of clay minerals in particular mechanical fractions of soil. Roczniki Gleboznawcze - Soil Science Annual, 32(3): 193-205.

Brogowski Z., Mazurek A., 1990. Stan mineralny ziaren o średnicy $<0.02 \mathrm{~mm} w$ glebie brunatnej wytworzonej z gliny zwałowej (Mineral state of grains with a diameter of $<0.02 \mathrm{~mm}$ in brown soil developed from boulder clay). Roczniki Gleboznawcze - Soil Science Annual, 41(1/2): 5-21. (in Polish)

Carter M.R., 1990. Relative measures of soil bulk density to characterize compaction in tillage studies on fine sandy loam. Canadian Journal of Soil Science, 70: 425-433.

Hakansson J., Lipiec J., 2000. A review of the usefulness of relative bulk density values in studies of soil structure and compaction. Soil and Tillage Research, 53: 71-85.

Keller T., Hakansson J., 2010. Estimation of reference bulk density from soil particle size distribution and soil organic matter content. Geoderma, 154: 398-406.

Lipiec J., Hakansson J., Tarkiewicz S., Kossowski J., 1991. Soil physical properties and growth of spring barley as related to the degree of compactness of two soils. Soil and Tillage Research, 19: 307-317.

Okołowicz M., Brogowski Z., 1996. Związki energetyczne we frakcjach granulometrycznych niektórych gleb (Energetic compounds in granulometric fractions of selected soils). Roczniki Gleboznawcze - Soil Science Annual, 47(suppl.): 31-41. (in Polish)

Raczuk J., 1987. Niektóre właściwości fizyczne gleb brunatnych i ich frakcji granulometrycznych (Selected physical properties of brown soils and their granulometric fractions). Roczniki Gleboznawcze - Soil Science Annual, 38(2): 221-232. (in Polish)

Turski R., Domżał H., Słowińska-Jurkiewicz A., 1974. Wpływ frakcji koloidalnej z uwzględnieniem próchnicy na maksymalna higroskopowość, granice konsystencji i pęcznienie gleb lessowych (Effect of the colloidal fraction with consideration of humus on the maximum hygroscopy, consistence boundaries, and swelling of loess soils). Roczniki Gleboznawcze Soil Science Annual, 25(3): 85-99. (in Polish)

Uziak S., Brogowski Z., Komornicki T., 2005. Właściwości frakcji granulometrycznych gleb wytworzonych z różnych utworów macierzystych. Rozprawy i Monografie (Properties of granulometric fractions of soils developed from various parent formations. Papers and monographs). Acta Agrophysica, 124: 159. (in Polish)

Wojtasik M., 1988: Gęstość naturalna gleb (Natural density of soils). Roczniki Gleboznawcze - Soil Science Annual, 39(3): 217-218. (in Polish)

Wojtasik M., 1989: Ocena gęstości gleb wytworzonych z glin zwałowych (Determination of the density of soils developed from boulder clays). Roczniki Gleboznawcze - Soil Science Annual, 40(2): 29-42. (in Polish)

Received: November 17, 2014

Accepted: February 12, 2015

\section{Obliczanie gęstości fazy stałej, gęstości objętościowej i porowatości gleby w oparciu o skład granulometryczny}

Streszczenie: Niniejsze opracowanie dotyczy weryfikacji współczynników zaproponowanych przez Brogowskiego (1990) do obliczania gęstość fazy stałej, objętościowej oraz porowatości ogólnej, w oparciu o skład granulometryczny. Zweryfikowane i uzupełnione współczynniki do wyliczenia gęstości fazy stałej, objętościowej i całkowitej porowatości pozwalają na uzyskanie wiarygodnych wyników, mieszczących się w granicach błędów analitycznych. Proponowane obliczenia gęstości i porowatości całkowitej gleb mogą służyć do ogólnej charakterystyki gleb. Natomiast nie mogą zastąpić ścisłych badań naukowych nad stanem fizycznym gleb.

Słowa kluczowe: gęstość fazy stałej, gęstość objętościowa, porowatość ogólna, skład granulometryczny 